\title{
PARIWISATA KERAKYATAN (COMMUNITY BASED TOURISM) DAN PENGARUHNYA PADA KESEJAHTERAAN PETANI DI DESA BUDAYA KERTALANGU KOTA DENPASAR
}

\author{
L.Pt.Kirana.Pratiwi ${ }^{1)}$, N.Sutjipta ${ }^{2)}$, I.G.Setiawan $\mathbf{A P}^{2)}$ \\ Program Studi Magister Agribisnis, Program Pascasarjana, Universitas Udayana, \\ E-mail: kirana.pratiwi92@gmail.com \\ 1) Mahasiswa Program Studi Magister Agribisnis, Program Pascasarjana, Universitas Udayana \\ ${ }^{2)}$ Staf Dosen Program Studi Magister Agribisnis, Program Pascasarjana, Universitas Udayana
}

\section{ABSTRACT \\ Community Based Tourism and Its Impacts to the Welfare of Farmers in Kertalangu Culture Village, Denpasar City}

The development of tourism in Bali until now has oriented in the mass tourism concept that was dominated by investors through the development of large scale facilities to boost the local revenue. In the short term, tourism gives significant benefits to economic, but in the long run it will become a boomerang for economy. An alternative to the tourism problem is the establishment of community based tourism which farmers as the subject directly involve in tourism. The purpose of this research is to analyze the influence of tourism, empowerment, and participation on increasing the welfare of farmers. The study had taken in Subak Padanggalak, Kertalangu Culture Village. The sample has done with purposive sampling which consist of 57 farmers. Technique analysis data using Partial Least Square (PLS) with Smart PLS program.

The research results show that tourism potential has significant impact on farmers empowerment, and it has followed by farmers empowerment also have significant impact on the farmer participation. In contrast, farmer's participation have not significant on increasing their welfare. This indicate that the farmer's participation have not give opimal benefit in supporting welfare of their life. Farmer have not look as the tourism subject. The role of farmers and subak have limited to support the tourism development, which the farmers have not involvement directly. It suggested the need that will be supported by private sector to develop agriculture to agrotourism. Trough the development of agrotourism a lot of agriculture commodities can be developed, and has been undertaken by various manufacturing agriculture products. The government through relevant agencies is expected to provide capital access and market acces as well as various guidance in managing agricultural products as a tourism product, thus farmer having high competitiveness on skill enhancement and improving their well-being.

Keywords: Community Based Tourism, Tourism Potential, Empowerment, Participation, the Welfare of Farmers. 


\section{PENDAHULUAN}

Bali menetapkan pariwisata sebagai leading sector karena telah terbukti mampu mendongkrak perekonomian Bali, dimana industri pariwisata menjadi andalan utama dalam Penerimaan Anggaran Daerah (PAD). Sebagai komuditas, pariwisata mencakup mata rantai kegiatan yang sangat panjang dan mampu menggerakkan sektor-sektor ekonomi lainnya dengan jangkauan yang sangat luas (Pujaastawa, 2005). Kebijakan pembangunan kepariwisataan saat ini lebih banyak menguntungkan pihak yang memiliki modal. Rakyat diibaratkan hanya sebagai 'sapi perah' yang hanya menyediakan objek wisata tanpa mendapatkan kesejahteraan yang semestinya. Masyarakat sebagai pemilik sah atas sumberdaya setempat justru kerap mengalami marginalisasi, sehingga menurunnya kualitas hidup masyarakat terhadap hak-hak komunitas budaya local.Peranan masyarakat sangat rendah, sehingga mereka cenderung atau tampak patuh dan tidak punya inisiatif karena lebih ditempatkan sebagai objek, bukan sebagai subjek utama. Hal ini terjadi karena pemerintah cenderung melakukan pendekatan pada pertumbuhan yang diukur dengan angka-angka statistik (growth oriented development), sehingga partisipasi masyarakat tidak mendapatkan perhatian dari yang memadai (Pitana, 2005).

Berbagai gejolak pariwisata tersebut membutuhkan suatu alternatif yang dapat memberikan kontribusi positif terhadap usaha peningkatan kesejahteraan masyarakat lokal adalah pengembangan pariwisata berbasis kerakyatan (community based tourism). Pembangunan kerakyatan merupakan pembangunan yang bersifat social learning dan pembangunan harus mulai dari bawah (bottom up), dimana lebih mengedepankan pentingnya pemberdayaan masyarakat yang memberikan banyak peluang kepada masyarakat lokal untuk berpartisipasi secara aktif dalam kegiatan-kegiatan pembangunan. Pengelolaan pembangunan harus benar-benar dilakukan oleh mereka yang hidup dan kehidupannya paling dipengaruhi oleh pembangunan tersebut. Hal ini berarti memberi wewenang atau kekuasaan kepada masyarakat lokal untuk memobilisasi kemampuan mereka sendiri dalam mengelola sumberdaya setempat. Kedudukan mereka adalah sebagai pemeran utama dalam membuat keputusan dan melakukan kontrol terhadap kebijakan-kebijakan yang mempengaruhi kehidupannya (Ardika, 2001).

Pengembangan pariwisata kerakyatan (community based tourism) diharapkan mampu meningkatkan kesejahteraan petani pada Desa Budaya Kertalangu. Areal jogging track pada sepanjang areal persawahan di tengah perkotaan mampu menarik motivasi wisatawan untuk berkunjung. Aktivitas pertanian, wisata buatan, eksebisi budaya, modal sosial, dan fasilitas yang disediakan Desa Budaya Kertalangu juga faktor pendukung dalam penentu kepuasan wisatawan. Posisi masyarakat setempat lebih memahami fenomena alam dan budayanya. Petani lokal merupakan bagian terpenting dan tidak terpisahkan dalam pembangunan kepariwisataan. Konsep ini kedepannya mampu menumbuhkan sikap masyarakat untuk lebih memiliki rasa tanggung jawab sebagai pelaku dalam membangun kepariwisataan lokal. Prinsip keberhasilan kepariwisataan tersebut tidak hanya menjadikan target utama menarik wisatawan asing untuk datang, akan tetapi lebih untuk mengembangkan peluang usaha-usaha masyarakat didalamnya untuk lebih berkembang dan mampu menarik minat wisatawan luar untuk datang. Oleh karena itu, peneliti ingin mengetahui pengaruh potensi wisata, pemberdayaan, dan partisipasi petani dalam upanya meningkatkan kesejahteraan petani di Desa Budaya Kertalangu. 


\section{Rumusan Masalah}

Berdasarkan latar belakang masalah yang telah dipaparkan di atas, maka masalah dalam penelitian ini dapat dirumuskan sebagai berikut :

1. Bagaimana pengaruh potensi wisata terhadap pemberdayaan petani di Desa Budaya Kertalangu Kota Denpasar?

2. Bagaimana pengaruh pemberdayaan petani terhadap partisipasi petani di Desa Budaya Kertalangu Kota Denpasar?

3. Bagaimana pengaruh partisipasi petani terhadap peningkatan kesejahteraan petani di Desa Budaya Kertalangu Kota Denpasar?

\section{Tujuan Penelitian}

Berdasarkan latar belakang dan rumusan masalah yang telah dikemukakan, maka tujuan dalam penelitian ini adalah :

1. Menganalisis pengaruh potensi wisata terhadap pemberdayaan petani di Desa Budaya Kertalangu Kota Denpasar.

2. Menganalisis pengaruh pemberdayaan petani terhadap partisipasi petani di Desa Budaya Kertalangu Kota Denpasar.

3. Menganalisis pengaruh partisipasi petani terhadap peningkatan kesejahteraan petani di Desa Budaya Kertalangu Kota Denpasar.

\section{KAJIAN PUSTAKA}

\section{Potensi wisata}

Amdani (2008) menyebutkan bahwa potensi wisata merupakan kemampuan dalam suatu wilayah yang mungkin dapat dimanfaatkan untuk pembangunan, seperti alam, sosial budaya, serta wisata dengan minat khusus. Menurut Yoeti (2001), suatu daya tarik wisata dapat menarik untuk dikunjungi oleh wisatawan jika memenuhi persyaratan antara lain: what to see (atraksi wisata yang unik dan menarik berbeda dengan daerah wisata lainnya; what to do (memiliki fasilitas rekreasi yang membuat wisatawan betah tinggal lama di tempat ini; what to buy (fasilitas belanja barang souvenir dan kerajinan rakyat sebagai oleh-oleh untuk di bawa pulang ke tempat asal ); what to arrived (aksesibilitas dalam mengunjungi wisata), serta what to stay (fasilitas tempat tinggal sementara selama berlibur). Suatu obyek wisata dapat menjadi salah satu obyek wisata yang menarik, jika keindahan wisata dilengkapi dengan sarana dan prasarana yang mendukung obyek wisata tersebut.

\section{Pemberdayaaan}

Pemberdayaan komunitas bertujuan untuk membentuk individu dan masyarakat menjadi mandiri yang mampu memunculkan potensi yang dimiliki masing-masing individu pada komunitas tersebut, sehingga individu mampu mengembangkan kreativitas serta kemampuan untuk menunjang tingkatkan kejahteraan mereka. Pitana (2005) menyebutkan bahwa keterlibatan masyarakat lokal merupakan kunci utama dalam pembangunan pariwisata, sehingga konsep pemberdayaan muncul sebagai usaha untuk memberikan masyarakat lokal agar terlepas dari ketidakmampuan bersuara (voicelessness) dan ketidakberdayaan (powerlessness) yang mencakup empat indikator utama yaitu: (1) kualitas sumber daya manusia, (2) akses terhadap berbagai informasi dalam pekerjannya, (3) akuntabilitas (tanggung jawab pelestarian masyarakat lokal, serta (4) kapasitas organisasi lokal dalam membina masyarakat untuk lebih berdaya. 


\section{Partisipasi}

Partisipasi dalam pembangunan pariwisata diartikan sebagai keterlibatan secara aktif dalam setiap proses pengembangan dari industri pariwisata, yaitu mulai dari perencanaan, penentuan rancangan, pelaksanaan, sampai dengan pengawasan dan pengevaluasian, dan penikmatan hasilnya (Hikmat, 2004). Keterlibatan masyarakat dalam proses tersebut menjadi kontrol yang sangat efektif dan menjamin pengembangan suatu obyek wisata sesuai dengan perencanaan. Pengaturan ketentuan tentang daya tampung suatu obyek wisata harus dilaksanakan dengan musyawarah yang melibatkan masyarakat lokal dan tidak berdasarkan atas kepentingan seseorang atau golongan. Masyarakat setempat harus mengawasi atau mengontrol pembangunan pariwisata dengan ikut terlibat dalam menentukan visi pariwisata, mengidentifikasi sumber-sumber daya yang akan dipelihara dan ditingkatkan, serta mengembangkan tujuan-tujuan dan strategi untuk pengembangan dan pengelolaan daya tarik wisata. Masyarakat juga harus berpartisipasi dalam mengimplementasikan strategi yang telah disusun sebelumnya.

\section{Kesejahteraan Petani}

Menurut Undang-undang Republik Indonesia No 11 Tahun 2009 Tentang Kesejahteraan Sosial, kesejahteraan sosial adalah kondisi terpenuhinya kebutuhan material, spiritual, dan sosial warga negara agar dapat hidup layak dan mampu mengembangkan diri, sehingga dapat melaksanakan fungsi sosialnya. Mudjiyo dalam Hikmat (2004) menyebutkan bahwa penyuluhan pertanian berperan penting dalam proses pembelajaran bagi pelaku utama (pelaku kegiatan pertanian) serta pelaku usaha agar mereka mau dan mampu menolong dan mengorganisasikan dirinya dalam mengakses informasi pasar, teknologi, permodalan, dan sumberdaya lainnya. Penyuluhan bertujuan untuk mengubah perilaku (pengetahuan, ketrampilan, sikap) petani agar sebagai upaya untuk meningkatkan produktivitas, efisiensi usaha, pendapatan, dan kesejahteraannya, serta meningkatkan kesadaran dalam pelestarian fungsi lingkungan hidup. Pencapaian kesejahteraan petani hanya akan terjadi jika lima indikator ini tercapai, yakni: (1) pertanian yang lebih baik (better farming); (2) berbisnis dengan lebih menguntungkan (better business); (3) kehidupan social yang lebih baik (better society); (4) lingkungan yang mendukung (better environtmen); (5) kehidupan yang lebih layak (better living) (Hikmat, 2004).

\section{KERANGKA KONSEP DAN HIPOTESIS}

\section{Kerangka Konsep}

Pembangunan kepariwisataan berbasis masyarakat (community based tourism) menuntut perubahan pendekatan dari pendekatan top down yang selama ini mendominasi proses pembangunan menjadi bottom up. Masyarakat merupakan bagian terpenting yang tidak terpisahkan dalam pembangunan kepariwisataan. Hal ini karena posisi masyarakat setempat lebih memahami fenomena alam dan kehidupan sosial budayanya. Selain itu, potensi wisata harus ditunjang oleh berbagai fasilitas yang mendukung, potensi wisata buatan yang menarik, serta aksesibilitas yang mudah dijangkau wisatawan. Potensi wisata apabila mampu dikemas sebagai produk wisata yang baik akan mampu meningkatkan kunjungan wisatawan. Petani dan aktivitas pertanian merupakan asset (daya tarik) utama Desa Budaya Kertalangu. Apabila petani lokal lebih diberdayakan baik dalam peningkatan mutu sumber daya petani, berbagai akses informasi, maupun kelembagaan pada sumber daya yang dimiliki, maka akan memiliki tanggung jawab moral untuk melestarikan sumber daya alam, maupun kehidupan sosial budaya yang menjadi bagian dari daya tarik utama wisata. Pemberdayaan petani akan berdampak juga secara langsung pada partisipasi petani pada aktivitas wisata Desa Budaya Kertalangu baik dalam proses perencanaan, pelaksanaan, maupun pengawasan 
wisata. Keterlibatan petani lokal sangat dipengaruhi pada insetif ekonomi (manfaat) yang diberikan pariwisata pada kesejahteraan hidupnya yang tercermin dengan adanya perubahan sikap mental, pandangan hidup, cara berpikir dan cara bekerja, sebagai subjek utama pariwisata. Pariwisata kerakyatan merupakan aktivitas ekonomi penting yang jika dikembangkan secara tepat bisa mengatasi sejumlah tantangan pembangunan, termasuk pengurangan kemiskinan, pengembangan ekonomi lokal, perdamaian dan keselarasan masyarakat, dan manajemen sumber daya alam dan lingkungan yang berkesinambungan.

Asumsi tersebut kemudian diuji dengan menggunakan rangkaian analisis meliputi analisis statistik deskriptif kualitatif dan analisis statistik inferensial dengan memanfaatkan model SEM sebagai langkah pengujiannya. Hasil penelitian kemudian disimpulkan yang memuat tentang potensi wisata, pemberdayaan, partisipasi petani, dan kesejahteraan sebagai sebuah kesimpulan empiris. Berdasarkan hasil penelitian disampaikan kepada petani dan pihak swasta pengelola Desa Budaya Kertalangu PT Bali Multi Wisata dengan harapan sebagai rekomendasi dalam upaya meningkatkan kesejahteraan petani.

\section{Hipotesis}

Berdasarkan rumusan masalah, kerangka berpikir dan kerangka konsep penelitian yang telah diuraikan sebelumnya, maka hipotesis dalam penelitian ini dapat dirumuskan sebagai berikut :

1. Potensi wisata berpengaruh signifikan terhadap pemberdayaan petani di Desa Budaya Kertalangu.

2. Pemberdayaan petani berpengaruh signifikan terhadap partisipasi petani di Desa Budaya Kertalangu.

3. Partisipasi petani tidak berpengaruh signifikan terhadap peningkatan kesejahteraan petani di Desa Budaya Kertalangu.

\section{METODE PENELITIAN}

Penelitian ini dilakukan pada petani Subak Padanggalak di Desa Budaya Kertalangu. Pelaksanaan penelitian ini melalui survai dalam rangka menguji hipotesis dan menjelaskan potensi pengembangan pariwisata kerakyatan (community based tourism) melalui potensi wisata, pemberdayaan petani, partisipasi petani dan pengaruhnya terhadap tingkat kesejahteraan petani Desa Budaya Kertalangu Denpasar. Sampel dalam penelitian ini adalah petani Desa Budaya Kertalangu di Subak Padanggalak. Pengambilan sampel dilakukan dengan metode purposive sampling. Jumlah responden ditentukan sebanyak 57 orang petani dari 134 petani pada Desa Budaya Kertalangu, pada total petani di Subak Padanggalak Desa Kesiman Kertalangu sebanyak 229 orang. Metode pengumpulan data melalui wawancara struktur dengan bantuan kuisioner. Penentuan responden dari seluruh pengurus dan anggota tersebut menggunakan formulasi teori Slovin (Sugiyono, 2009). Penelitian ini juga dilakukan wawancara mendalam (in-depth interview) pada informan kunci seperti: Kepala Desa Kertalangu, pimpinan PT Bali Multi Wisata selaku pengelola kawasan Desa Kertalangu, Pekaseh Subak Padanggalak, serta tokoh masyarakat setempat. Metode pengumpulan data penelitian ini juga dilengkapi dengan dokumentasi dan studi kepustakaan.

Terdapat tiga variabel eksogen, yaitu potensi wisata $(\mathrm{PW})$, pemberdayaan petani $(\mathrm{Pm})$, dan partisipasi petani (Pr), sedangkan variabel endogennya adalah kesejahteraan petani 
(Be). Variabel-variabel yang telah disampaikan merupakan variabel laten (unobserved) yang diukur dari beberapa indikator. Tiap-tiap indikator terdiri atas beberapa item yang dijabarkan dalam instrumen penelitian sebagai variabel terobservasi. Indikator pada potensi wisata (PW) terdiri dari potensi alam (PW1), potensi buatan (PW2), modal sosial (PW3), aksesibilitas (PW4), dan fasilitas penunjang wisata (PW5). Indikator pada pemberdayaan petani (Pm) yang terdiri dari sumber daya manusia (Pm1), akses informasi (Pm2), akuntabilitas (Pm3), serta kelembagaan (Pm4). Indikator pada partisipasi petani $(\mathrm{Pr})$ yang terdiri dari perencanaan wisata (Pr1), pelaksanaan wisata $(\operatorname{Pr} 2)$, pengawasan wisata $(\operatorname{Pr} 3)$, serta pemanfaatan wisata $(\mathrm{Pr} 4)$. kesejahteraan petani $(\mathrm{Be})$ terdiri dari 5 indikator yaitu pertanian yang lebih baik (better farming) (BF), berbisnis yang menguntungkan (better bussiness) (BB), kehidupan sosial yang lebih baik (better society) (BS), lingkungan yang mendukung (better environtmen) (BE), serta kehidupan yang lebih layak (better living) (BL), selanjutnya dianalisis menggunakan Partial Least Square (PLS) yang diaplikasikan dalam software SmartPLS 2.0. Alasan digunakan metode analisis PLS ini, karena tidak mengasumsikan data harus menggunakan pengukuran skala tertentu, digunakan pada jumlah sampel kecil (30-50 unit atau $<100$ unit), dan juga dapat digunakan untuk konfirmasi teori (Ghozali, 2012).

Evaluasi model pada SEM (PLS) terdiri atas evaluasi model pengukuran (outer model), model struktural (inner model) dan pengujian hipotesa. Evaluasi model pengukuran (outer model) menunjukkan pada valuasi pada convergent validity menunjukkan semua indikator memiliki nilai outer loading $>0,70$ dan nilai $t$-statistic $>1,96$. Discriminant validity menunjukkan akar kuadrat AVE untuk setiap konstruk lebih besar dari korelasi antar konstruk dalam model. Composite Reliability dan Cronbach's Alpha menunjukkan bahwa variabel laten potensi wisata $(\mathrm{PW})$, pemberdaayaan $(\mathrm{Pm})$, partisipasi $(\mathrm{Pr})$, dan kesejahteraan (Be) menunjukan nilai di atas 0,70. Selanjutnya, pada evaluasi inner model menunjukkan bahwa pemberdayaan (Pm) memiliki nilai $R$-Square 0,921 hal ini berarti pemberdayaan (pm) mampu menjelaskan varian potensi wisata (PW) sebesar 92,10\%. Partisipasi (Pr) memiliki nilai $R$-Square 0,840 hal ini berarti partisipasi (pr) mampu menjelaskan varian pemberdayaan (Pm) sebesar 84,00 \% Kesejahteraan Petani (Be) memiliki nilai $R$-Square 0,988 hal ini berarti Kesejahteraan $(\mathrm{Be})$ mampu menjelaskan varian partisipasi petani $(\mathrm{Be})$ sebesar $61,50 \%$. Evaluasi model struktural dengan melihat nilai $\mathrm{Q}^{2}$ sebesar $0,995\left(\mathrm{Q}^{2}>0\right)$. Hasil evaluasi ini menunjukkan bahwa model struktural memiliki predictive relevance. Selanjutnya evaluasi model struktural dengan melihat nilai GoF (Goodness of Fit) menunjukkan nilai 0,995. Hasil evaluasi ini menunjukkan bahwa bahwa model struktural memiliki kesesuaian (goodness of fit model) yang baik. Hal ini berarti bahwa informasi yang terkandung dalam data 99,50\% dapat dijelaskan oleh model sedangkan sisanya $0,50 \%$ dijelaskan variabel lain yang belum terdapat dalam model. Pengujian koefisien jalur struktural dilakukan untuk menjawab hipotesis penelitian dan juga untuk mengetahui besarnya pengaruh masing-masing variabel. Hasil pengujian model dan hipotesis dapat dilihat pada Tabel 1 dibawah ini. 
Tabel 1

Koefisien Jalur Struktural

\begin{tabular}{rlrrl}
\hline No & Hubungan Antar Variabel & $\begin{array}{r}\text { Koefisien } \\
\text { Jalur }\end{array}$ & T-Statistic & Keterangan \\
\hline 1 & $\begin{array}{l}\text { Potensi Wisata (PW)-> } \\
\text { Pemberdaayaan Petani (Pm) }\end{array}$ & 0,960 & 5,453 & Signifikan \\
2 & $\begin{array}{l}\text { Pemberdayaan Petani (Pm)-> } \\
\text { Partisipasi Petani (Pr) }\end{array}$ & 0,916 & 5,262 & Signifikan \\
3 & $\begin{array}{l}\text { Partisipasi Petani (Pr)-> } \\
\text { Kesejahteraan Petani (Be) }\end{array}$ & 0,784 & 1,453 & Tidak Signifikan \\
\hline Sumber : Hasil Analisis Data Responden & & & \\
\hline
\end{tabular}

Sumber : Hasil Analisis Data Responden

Berdasarkan Tabel 1 diatas, dapat dinyatakan bahwa potensi wisata (PW) terhadap pemberdayaan $(\mathrm{Pm})$ dan pemberdayaan $(\mathrm{Pm})$ terhadap partisipasi petani $(\mathrm{Pr})$ berpengaruh positif dan signifikan yang ditunjukkan melalui nilai koefisien jalur yang bernilai positif dan T-statistik $>1$,96. Namun, partisipasi $(\mathrm{Pr})$ terhadap kesejahteraan petani $(\mathrm{Be})$ berpengaruh positif dan tidak signifikan yang ditunjukkan melalui nilai koefisien jalur yang bernilai positif dan T-statistik $<1,96$.

\section{HASIL PENELITIAN DAN PEMBAHASAN}

Hasil analisis deskriptif menunjukkan bahwa rata-rata skor untuk variabel potensi wisata (PW) adalah 3,6 (baik). Berdasarkan 5 indikator yang digunakan untuk mengukur variabel potensi wisata $(\mathrm{PW})$, nilai rata-rata skor terendah jawaban responden pada indikator fasilitas penunjang wisata (PW5) dengan skor 3,3 (cukup baik). Selanjutnya, rata-rata skor untuk variabel pemberdayaan (Pm) adalah sebesar 3,2 (cukup baik). Rata-rata skor jawaban terendah dari 4 indikator yang digunakan adalah akses informasi (Pm2) dengan skor rata-rata 2,5 yang berada dalam kategori kurang baik. Selanjutnya, rata-rata skor untuk variabel partisipasi (pr) adalah sebesar 3,3 (cukup baik). Rata-rata skor jawaban terendah dari 4 indikator yang digunakan berada pada indikator pemanfaatan wisata (Pr4) dengan skor ratarata 2,5 yang berada dalam kategori kurang baik. Kemudian, rata-rata skor variabel kesejahteraan petani di Desa Budaya Kertalangu adalah 2,5 (kurang baik). Rata-rata skor terendah dari 5 indikator yang digunakan adalah indikator better bussiness (BB) dengan nilai rata-rata 1,9 (kurang baik). 
Hasil Pengujian hipotesis yang diajukan dalam penelitian ini dapat dilihat pada gambar berikut.

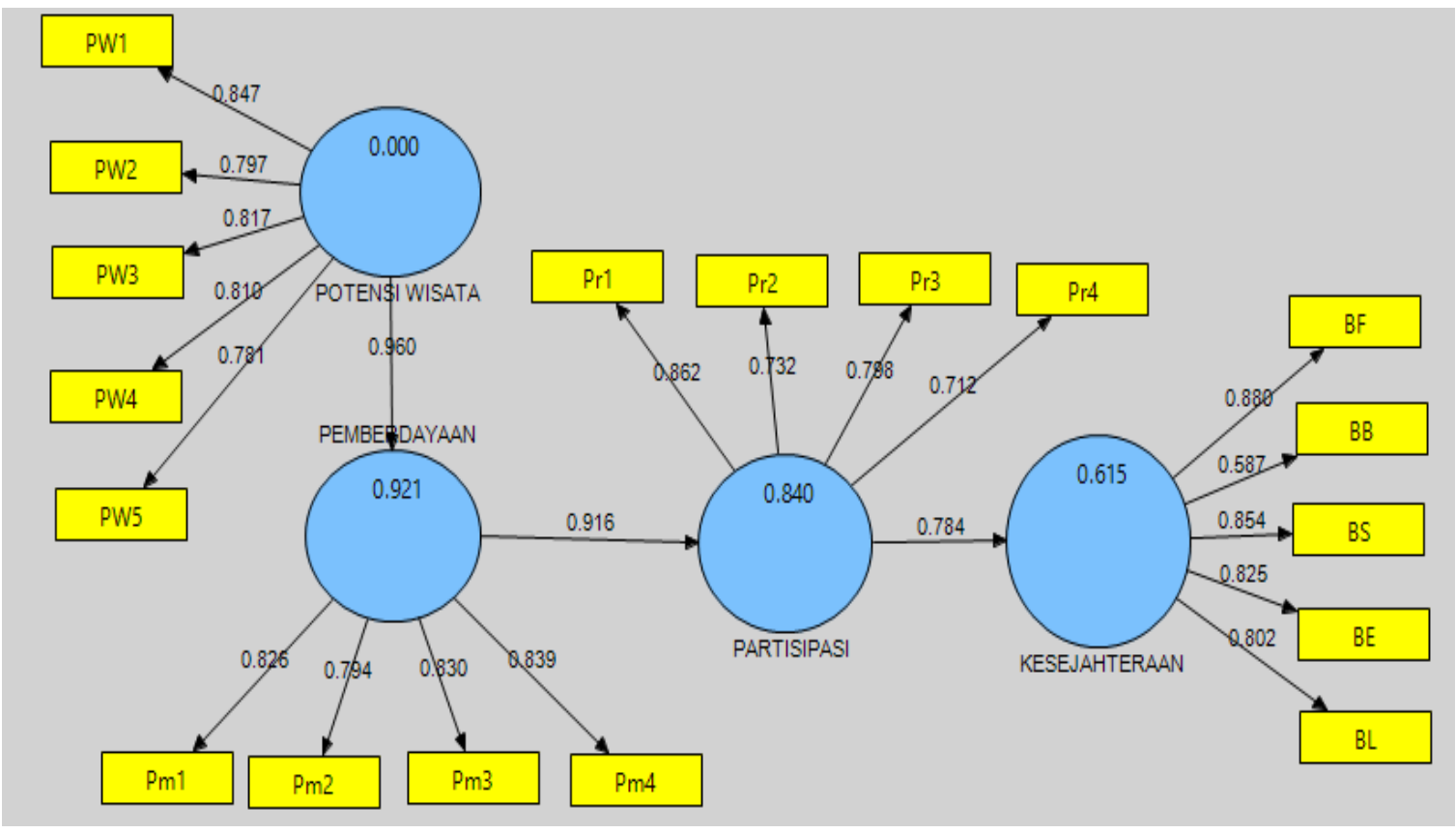

Gambar 1

Model Struktural Pariwisata Kerakyatan dan Pengaruhnya terhadap Kesejahteraan Petani Di Desa Budaya Kertalangu

Hasil penelitian menunjukkan bahwa potensi wisata berpengaruh signifikan terhadap pemberdayaan petani. Hal ini dibuktikan dengan koefisien jalur yang bernilai positif sebesar 0,960 dengan nilai $t_{\text {statistik }}$ sebesar 5,453 $\left(\mathrm{t}_{\text {statistik }}>1,96\right)$. Diantara indikator yang digunakan untuk mengukur variabel potensi wisata $(\mathrm{PW})$, indikator potensi alam memiliki nilai penciri tertinggi sebesar 0,847 . Parameter potensi alam memiliki skor terkecil yakni mengembangkan berbagai komoditi dalam lahan pertanian dengan skor 3,8. Untuk meningkatkan potensi wisata dapat dimulai dengan meningkatkan potensi alam yaitu mengembangkan komoditi lain selain padi yaitu berbagai komoditi yang menguntungkan dengan sistem tumpang sari. Hal ini karena potensi wisata alam (pada pertanian) di tengah perkotaan dengan ditunjang berbagai atraksi wisata merupakan potensi wisata yang sangat menarik untuk meningkatkan motivasi wisatawan dalam berkunjung, sehingga memiliki kemampuan untuk memberdayakan kehidupan masyarakat lokal khususnya petani. Hasil penelitian ini berhubungan dengan penelitian yang dilakukan oleh Satiyono (2009) apabila ditinjau dari segi perekonomian masyarakat, desa wisata memberikan manfaat untuk semua pihak yang terlibat di mana aktivitas wisata mampu memberdayakan masyarakat untuk melayani wisatawan dalam mengembangkan daya tarik (potensi) wisata berupa potensi alam maupun potensi masyarakat desa yang dimiliki daerahnya. Suwantoro (2001) menyebutkan bahwa potensi wisata merupakan kemampuan dalam suatu wilayah yang dapat dimanfaatkan untuk pembangunan wisata. Potensi yang dimiliki masyarakat dari dalam dirinya untuk mampu 
mengelola lahan dan aktivitas pertaniannya akan mampu meningkatkan kualitas hidup ke depannya.

Selanjutnya, pemberdayaan petani berpengaruh signifikan terhadap partisipasi petani. Hal ini dibuktikan melalui nilai koefisien jalur yang positif sebesar 0,826 nilai $t_{\text {statistik }}$ sebesar $5,262\left(\mathrm{t}_{\text {statistik }}>1,96\right)$. Berdasarkan 4 indikator pada variabel pemberdayaan $(\mathrm{PM})$, indikator akuntabilitas memiliki nilai penciri tertinggi sebesar 0,20. Parameter akuntabilitas yang memiliki skor terkecil adalah memberikan pelayanan yang baik pada wisatawan dengan skor 3,2. Untuk meningkatkan pemberdayaan dapat dimulai dengan meningkatkan kemampuan petani dalam memberikan pelayanan bagi wisatawan. Dalam upaya mempertahakan jalur hijau (pertanian), petani mengharuskan dirinya terlibat (berpartisipasi) dalam keberlanjutan wisata melalui pelestarian alam, budaya, maupun lingkungannya dalam pengembangan wisata Desa Budaya Kertalangu. Hal ini karena proses permberdayaan melibatkan masyarakat (partisipasi) dalam melakukan kajian masalah, merencanakan, melaksanakan maupun melakukan evaluasi pada program pengembangan wisata yang telah direncanakan bersama. Partisipasi merupakan faktor utama dalam keberhasilan program pemberdayaan, yang mana tinggi rendahnya sangat dipengaruhi dari faktor internal maupun eksternal masyarakat itu sendiri. Partisipasi berperan untuk meningkatkan kepedulian masyarakat terhadap permasalahan sekitar, meningkatkan taraf kehidupan maupun kemandirian masyarakat itu sendiri. Hasil penelitian ini mendukung penelitian yang dilakukan oleh Cahyo Susmito (2013) menyebutkan bahwa pemberdayaan masyarakat desa adalah memberikan manfaat ekonomi dalam hidupnya, sehingga semua pihak ikut terlibat dalam mengelola desa wisata. Pemberdayaan dikaitkan dengan penggalian dan pengembangan potensi masyarakat yang hanya bisa terjadi apabila warganya ikut berpartisipasi. Kartasasmita, dkk (2001) menyebutkan bahwa setiap manusia memiliki potensi yang dapat dikembangkan, sehingga pemberdayaan adalah upaya untuk membangun daya itu dengan mendorong, memberikan motivasi dan membangkitkan kesadaran akan potensi yang dimiliki serta untuk mengembangkannya. Keterlibatan masyarakat lokal sangat penting dalam menentukan keberhasilan suatu program pembangunan, karena akan menumbuhkan rasa kesadaran dan tanggung jawab masyarakat yang tercermin dengan adanya perubahan sikap mental, pandangan hidup, cara berpikir, dan cara bekerja.

Kemudian, partisipasi petani tidak berpengaruh signifikan terhadap kesejahteraan petani. Hal ini dibuktikan melalui nilai koefisien jalur yang positif sebesar 0,784 nilai $t_{\text {statistik }}$ sebesar 1,453 $\left(\mathrm{t}_{\text {statistik }}<1,96\right)$. Berdasarkan 4 indikator pada variabel partisipasi $(\operatorname{Pr})$, indikator perencanaan wisata memiliki nilai penciri tertinggi sebesar 0,862, namun pemanfaatan wisata memiliki skor yang paling rendah yakni 0,712. Hal ini karena keterlibatan petani dalam pemanfaatan wisata belum mendapatkan benefit yang optimal dalam menunjang kesejahteraan hidupnya. Ini karena pengembangan wisata di Desa Budaya Kertalangu masih dikelola sepenuhnya oleh pihak swasta yang mengutamakan program wisata dalam meningkatkan profit usaha. Petani belum terlihat sebagai subjek pariwisata. Peran petani dan subaknya hanya sebatas mendukung pengembangan wisata yang mana keterlibatan langsungnya belum terlihat optimal. Hasil penelitian sebagaimana telah disampaikan melalui analisis tersebut berhubungan dengan penelitian yang dilakukan oleh Heni Urmila (2013) menyebutkan bahwa pengembangan berbasis desa wisata di Jatiluwih belum melibatkan Kirana Pratiwi, et.al., Pariwisata Kerakyatan ... | 9 
masyarakat lokal. Hal ini karena sawah dan petani merupakan aset pariwisata yang dijual untuk kepentingan wisatawan namun pengembangan desa wisata tidak berpihak pada kehidupan petani dimana sawah yang dikelola mereka tidak berkembang. Petani tetap miskin sementara investor meraup keuntungan besar dari aktivitas pariwisata. Pariwisata yang melibatkan masyarakat (partisipasi) memiliki bagian yang sangat penting karena memiliki hubungan yang kuat dalam mencapai kesejahteraan yang efektif untuk memberikan kemakmuran dan pemerataan di bidang ekonomi, sosial, dan lingkungan. Pengembangan desa sebagai objek wisata perlu dipahami dari awal bahwa masyarakat setempat bukan objek pasif namun sebagai subjek utama yang seharusnya aktif dalam pariwisata. Menurut Isbandi (2007), partisipasi adalah proses ketika warga sebagai individu maupun kelompok sosial dan organisasi, mengambil peran serta ikut mempengaruhi proses perencanaan, pelaksanaan, dan pemantauan kebijakan kebijakan yang langsung mempengaruhi kehiduapan mereka.

\section{SIMPULAN DAN SARAN}

\section{Simpulan}

Berdasarkan hasil analisis dan pembahasan yang telah dilakukan dalam penelitian ini, maka dapat diperoleh simpulan sebagai berikut :

1. Potensi wisata berpengaruh signifikan terhadap pemberdayaan petani Desa Budaya Kertalangu. Indikator potensi alam memiliki nilai penciri tertinggi.

2. Pemberdayaan petani berpengaruh signifikan terhadap partisipasi petani Desa Budaya Kertalangu. Indikator akuntabilitas memiliki nilai penciri tertinggi.

3. Partisipasi petani tidak berpengaruh signifikan terhadap kesejahteraan petani Desa Budaya Kertalangu. Indikator perencanaan wisata memiliki nilai penciri tertinggi, namun dalam pemanfaatan memiliki nilai terendah.

\section{Saran}

Berdasarkan hasil analisis dan pembahasan yang telah dilakukan dalam penelitian ini, maka dapat diberikan beberapa saran sebagai berikut :

1. Dalam upaya meningkatkan peran petani sebagai subjek pariwisata, diperlukan dukungan sektor swasta (investor) untuk mengembangkan pertanian menuju agrowisata.

2. Pihak pengelola Desa Budaya Kertalangu pun diharapkan mampu berperan tidak hanya sebagai manajer di bidang pariwisata tapi juga selaku manajer pertanian melalui bantuan sarana produksi (saprodi), mengembangkan berbagai komoditi yang menguntungkan selain padi, serta dalam pemasaran hasil produksi melalui pasar oleh-oleh, restoran yang dikelola DBK, maupun berusaha (berdagang) pada acara-acara besar yang diadakan dalam mendukung keberlanjutan pengembangan agrowisata.

3. Pemerintah melalui Dinas terkait diharapkan memberikan bantuan berupa (a) Akses modal dalam mendukung kontinyuitas sarana produksi dan usaha wisata dalam bentuk koperasi yang dikelola petani; (b) Memberikan akses pasar melalui berbagai acara-acara besar yang melibatkan petani di dalamnya seperti pameran pertanian beras organik, buah lokal, maupun festival pertanian di Desa Budaya Kertalangu; serta (c) Berbagai penyuluhan dan pembinaan bagi petani dalam mengelola produk pertanian sebagai produk wisata sehingga 
petani selaku subjek pariwisata memiliki daya saing yang tinggi dalam meningkatkan skill maupun hasil produksinya yang berdampak pada peningkatan kesejahteraan hidupnya.

\section{Ucapan Terima Kasih}

Melalui media ini saya menyampaikan ucapan terima kasih yang tulus kepada Prof. Dr. Ir. I Nyoman. Sutjipta, MS (Pembimbing I) dan Dr. I Gede Setiawan Adi Putra, SP, M.Si (Pembimbing II), keluarga, dan teman-teman seperjuangan atas bimbingan serta dukungan semangat yang telah diberikan, sehingga saya dapat menyelesaikan tesis ini dengan baik.

\section{Daftar Pustaka}

Ardika, I Wayan, 2001. Pembangunan Pariwisata Bali Berkelanjutan Yang berbasis Kerakyatan. Denpasar: Udayanan University Press

Gozali, Imam, Hengki Latan. 2012. Partial Least Squares. Konsep, Teknik, dan Aplikasi Smart PLS 2.0 M3 untuk Peneliti Empiris. Semarang: badan Penerbit Universitas Diponogoro.

Hikmat, H. 2004. Strategi Pemberdayaan Masyarakat. Bandung: Humaniora.

Heny Urmila Dewi, Made. 2013. Pengembangan Desa Wisata Berbasis Partisipasi Masyarakat Lokal di Desa Jatiluwih Tabanan, Bali. Denpasar: Kawistara. Volume 3, No. 2, 17 Agustus 2013 Halaman 117-226.

Isbandi, Rukminto. 2007. Perencanaan Partisipatoris Berbasis Aset Komunitas: Dari Pemikiran Menuju Penerapan. FISIP UI Press.Depok

Jamasy, O. 2004. Keadilan, Pemberdayaan, \& Penanggulangan Kemiskinan. Jakarta Selatan: Blantika.

Kartasasmita, Ginandjar, 2001. Pembangunan Untuk Rakyat: Memadukan Pertumbuhan Dan Pemerataan. Jakarta : Pustaka CIDESINDO

Murdianto, Eko. 2011. Partisipasi Masyarakat dalam Pengembangan Desa Wisata Karanggeneng Purwobinangun Pakem Sleman. http://agribisnis.fp.uns.ac.id/wpcontent/uploads. Diakses Tgl 3 November 2016.

Pitana, I Gde dan Putu G. Gayatri. 2005. Sosiologi Pariwisata. Yogyakarta: Andi. Prasiasa.

Pujaastawa, I B G, Wirawan I GP, Adhika I M. 2005. Pariwisata Terpadu Alternatif Model Pengembangan Pariwisata Bali Tengah. Denpasar: Universitas Udayana Press.

Susmito, Cahyo. 2014. Pengembangan Desa Wisata Berbasis Pemberdayaan Masyarakat dalam Pembangunan Ekonomi. http://agribisnis.fp.uns.ac.id/wp-content/uploads. Diakses Tgl 3 November 2016.

Sugiyono, 2009. Metode Penelitian Kuantitatif Kualitatif dan R\&D. Jakarta: CV. Alfabeta.

Sutiyono. 2009. Pemberdayaan Masyarakat Desa dalam Pelaksanaan Program Desa Wisata di Daerah Istimewa Yogyakarta .http://staff.uny.ac.id/sites/default/files/091808675/JurnalKepatihan.pdf. Diakses Tgl 3 November 2016.

Suwantoro, Gamal. 2001. Dasar-Dasar Pariwisata. Yoyakarta : ANDI Yogyakarta.

Yoeti, Oka A. 2002. Perencanaan Strategis Pemasaran Daerah Tujuan Wisata. Jakarta: PT. Pradnya Paramita. 